\title{
Fourth-quarter biotech job picture
}

\author{
A quarterly snapshot of job expansions, reductions and availability in the biotech and pharma sectors.
}

\begin{abstract}
T he final quarter of 2019 saw the opening of several new pharma manufacturing facilities worldwide. In October, BeiGene launched the first phase of a $\$ 331$ million manufacturing base in Guangzhou, China, that it will use for commercial manufacturing of oncology drugs. It is expected to employ 200 people. Also in October, Johnson \& Johnson opened a 206,000-square-foot addition to its operations in Ringaskiddy, Ireland. J\&J also expects to add 200 jobs. Finally,
\end{abstract}

\begin{tabular}{|c|c|c|c|c|}
\hline \multirow[t]{2}{*}{ Company ${ }^{a}$} & \multirow[t]{2}{*}{$\begin{array}{l}\text { Number of } \\
\text { employees }\end{array}$} & \multicolumn{3}{|c|}{$\begin{array}{l}\text { Number of advertised } \\
\text { openings }^{b}\end{array}$} \\
\hline & & Monster & Linkedln & Biospace \\
\hline Shire & 23,044 & 0 & 1,950 & 0 \\
\hline Amgen & 20,800 & 59 & 1,897 & 666 \\
\hline Monsanto & 20,500 & 9 & 93 & 0 \\
\hline Gilead Sciences & 10,000 & 14 & 532 & 27 \\
\hline bioMérieux & 9,971 & 0 & 105 & 0 \\
\hline Biocon & 9,234 & 0 & 16 & 0 \\
\hline IDEXX Laboratories & 7,600 & 0 & 436 & 0 \\
\hline Celgene & 7,467 & 224 & 399 & 44 \\
\hline Biogen & 7,300 & 0 & 808 & 0 \\
\hline Regeneron Pharmaceuticals & 6,200 & 3 & 542 & 652 \\
\hline Illumina & 6,200 & 65 & 547 & 0 \\
\hline Novozymes & 6,109 & 0 & 19 & 1 \\
\hline Opko Health & 6,030 & 3 & 106 & 0 \\
\hline Endo Pharmaceuticals & 3,039 & 64 & 56 & 0 \\
\hline BGI Genomics & 2,585 & 0 & 3 & 0 \\
\hline BioMarin Pharmaceutical & 2,581 & 0 & 201 & 8 \\
\hline Alexion Pharmaceuticals & 2,525 & 0 & 301 & 0 \\
\hline Biotest & 2,474 & 1 & 424 & 0 \\
\hline Myriad Genetics & 2,400 & 2 & 170 & 0 \\
\hline Vertex Pharmaceuticals & 2,300 & 48 & 280 & 0 \\
\hline Evotec & 2,178 & 0 & 21 & 19 \\
\hline Alkermes & 2,000 & 42 & 67 & 0 \\
\hline GenScript Biotech & 1,932 & 0 & 0 & 0 \\
\hline CK Life Sciences & 1,688 & 0 & 0 & 0 \\
\hline Amphastar Pharmaceuticals & 1,644 & 0 & 5 & 0 \\
\hline Total & & 532 & 8,973 & 1,417 \\
\hline
\end{tabular}

${ }^{a}$ As defined in Nature Biotechnology's survey of public companies $(36,576-584 ; 2018) .{ }^{b}$ As searched on Monster.com, Linkedln.com and Biospace.com, 7 January 2020. Jobs may overlap.
Novartis inaugurated a new cell and gene therapy manufacturing facility in Stein, Switzerland at the end of November. The new facility will add 265 employees to its current 185 and will allow Novartis to manufacture tailored cell therapies such as Kymriah (tisagenlecleucel) for European patients. Previously, the treatment required shipment from Novartis's facility in Morris Plains, New Jersey.

Merck announced in October that it was cutting 500 jobs in its US sales and commercial teams. In November, it shuttered a toxicology R\&D site in Riom, France, saying that the decreasing number of studies performed there no longer "made it possible to ensure optimal use of the center's capacity." Also in October,

Eli Lilly announced the closure of its Erl Wood neuroscience center in Surrey, UK. The center will shut down at the end of 2020 and lay off 80 employees. Another 270 employees will be moved to a new location nearby, as the company's neuroscience research will shift to a center in the United States.

Advertised biotechnology and pharmaceutical sector jobs in the databases tracked by Nature Biotechnology were slightly up in the fourth quarter of 2019 (Tables 1 and 2) compared with the previous quarter (Nat. Biotechnol. 37, 1381, 2019).

Table 2 | Advertised job openings at the ten largest pharma companies

\begin{tabular}{lllll} 
Company & $\begin{array}{l}\text { Number of } \\
\text { employees }\end{array}$ & \multicolumn{2}{l}{ Number of advertised openings ${ }^{\mathrm{b}}$} \\
\cline { 3 - 5 } & & Monster & Linkedln & Biospace \\
\hline Johnson \& Johnson & 134,000 & 4,836 & 2,750 & 1 \\
\hline Novartis & 125,000 & 29 & 3,275 & 192 \\
\hline Sanofi & 106,600 & 41 & 1,743 & 0 \\
\hline Bayer & 99,900 & 54 & 827 & 0 \\
\hline Abbott Laboratories & 99,000 & 3 & 2,082 & 7 \\
\hline GlaxoSmithKline & 98,500 & 1 & 2,687 & 0 \\
\hline Roche & 93,700 & 4 & 4,784 & 3 \\
\hline Pfizer & 90,200 & 1 & 470 & 0 \\
\hline Merck \& Co. & 69,000 & 3 & 462 & 0 \\
\hline Sinopharm & 61,700 & 0 & 4 & 0 \\
\hline Total & & 4,972 & 19,084 & 203 \\
\hline
\end{tabular}

a Data obtained from Statista. ${ }^{b}$ As searched on Monster.com, Linkedln.com and Biospace.com, 7 January 2020. Jobs may overlap.

Michael Francisco

Senior Editor, Nature Biotechnology.

Published online: 7 February 2020

https://doi.org/10.1038/s41587-020-0416-4 